\title{
The effectiveness of health systems in influencing avoidable mortality: a study in Valencia, Spain, 1975-90
}

\author{
Xavier Albert, Asunción Bayo, Jose L Alfonso, Pedro Cortina, Dolores Corella
}

\begin{abstract}
Objectives - To measure variations in the Holland and Charlton classifications of avoidable death causes and to estimate the effect of the Spanish national health system on avoidable mortality.

Design - Mortality in the Valencian Community was assessed between 1975 and 1990. The classifications of Holland and Charlton, used to assess avoidable causes of death, were compared. Holland's classification was then used to divide avoidable mortality into two groups - medical care indicators (MCI), which show the effectiveness of health care, and national health policy indicators (NHPI), which show the status of primary prevention. Comparisons were made with rates, group rates, and population rates. Trends and indices were also studied.

Setting - Valencia, Spain, 1975-90.

Results - During the study period, avoidable morality (only assessed by MCI) fell $63 \%$, whereas the remainder of the mortality (non-MCI causes, that is all the nonavoidable causes together with the NHPI group) fell by $17 \%$. If it is assumed that the mortality due to non-MCI causes indicates the overall effect of the environmental, social, nutritional, and genetic influences, then the difference between this and the MCI group would take us nearer the actual effect of the intervention of the health system.

Conclusions - It is concluded that in this community, the health system has been responsible for approximately $47 \%$ of the total reduction in mortality from avoidable causes in the period studied.
\end{abstract}

Consellería de Sanidad y Consumo, Servicio Valenciano de la Salud, Valencia, Spain $\mathrm{X}$ Albert

A Bayo

Departamento de Medicina Preventiva y Salud Pública Universidad de Valencia, Av Blasco Ibañez, 17 46010 Valencia, Spain $\mathrm{J}$ L Alfonso

P Cortina

D Corella

Correspondence to: Prof J L Alfonso.

Accepted for publication November 1995

\section{(F Epidemiol Community Health 1996;50:320-325)}

It is obvious that the objective of a health system is the application of the best current scientific knowledge in real conditions. However, when the theoretical foundations indicate that a specific pathology is avoidable while practice shows the opposite, it seems necessary to assess the quality of the health care.

Rutstein 12 made a list of "unnecessary untimely mortality" in order to assess the quality of the health care; however, it was Charlton et $a l^{3}$ who carried out the study of the community referring to those causes as avoidable and as possible indicators of the effectiveness of the health services. Numerous studies have been done since, ${ }^{4-9}$ the most important being the Project of Coordinated Action of the European Community, directed by Holland and published in 1988, which became the Atlas of Avoidable Death, ${ }^{10}$ with a second update in $1991 .{ }^{11}$ This study attempted to unify the list of avoidable mortality causes.

In practical terms, all studies on avoidable mortality use a selection of causes based on Rutstein's original list and generally omit infrequent causes of mortality. Many also omit causes, such as lung cancer and hepatic cirrhosis (originally included in Rutstein's list) and motor accidents (not included), whose avoidance is outside the scope of the health care services and belongs instead to the primary prevention field. The separation into causes that are amenable to secondary prevention or medical treatment (medical care indicators (MCI)) and those that are avoidable through primary prevention (national health policy indicators (NHPI)) comes from Holland's work, ${ }^{1011}$ and has been continued in some national ${ }^{1213}$ and international studies.

To study the evolution of avoidable mortality in the Valencian Community between 1975 and 1990 we compared the two most representative lists of death causes - those of Holland and Charlton. We aimed to assess mortality trends for both the MCI and NHPI.

\section{Methods}

The autonomous Valencian Community is in the east of Spain and has an approximate population of 4 million people, a $2.5 \%$ vegetative growth rate, and a birth rate of 11 per 1000 inhabitants. The work force is mainly involved in the service sector, specifically in tourism but industry and farming are also important and represent $15 \%$ of the gross domestic product of Spain.

DATA

The data were collected directly from the $\mathrm{Na}$ tional Statistics Institute (1975-86) and from the mortality registry of the Valencian Community (1987-90). Mortality data bases were created. These included five year age groups up to 75 years (the first five year period was divided into two groups, $0-1$ and $1-4$ years, as there are causes which are avoidable for the first year) and sex groups for each of the selected death causes and for the total of causes, during the period 1975-90. 
Table 1 Avoidable mortality selected causes, Holland's classification

\begin{tabular}{|c|c|c|c|}
\hline Cause & Age (y) & $I C D-8$ & $I C D-9$ \\
\hline $\begin{array}{l}\text { Secondary prevention, or medical care indicators } \\
1 \text { Tuberculosis } \\
2 \text { Malignant neoplasms of cervix uteri } \\
3 \text { Malignant neoplasms of cervix and body of uterus } \\
4 \text { Hodgkin's disease } \\
5 \text { Chronic rheumatic heart disease } \\
6 \text { Respiratory diseases } \\
7 \text { Asthma } \\
8 \text { Appendicitis } \\
9 \text { Abdominal hernia } \\
10 \text { Cholelithiasis and cholecystitis } \\
11 \text { Hypertensive and cerebrovascular disease } \\
12 \text { Typhoid } \\
13 \text { Whooping cough } \\
14 \text { Tetanus } \\
15 \text { Measles } \\
16 \text { Osteomyelitis } \\
17 \text { Maternal deaths* } \\
18 \text { Perinatal mortality }\end{array}$ & $\begin{array}{r}5-64 \\
15-64 \\
15-64 \\
5-64 \\
5-44 \\
1-14 \\
5-44 \\
5-64 \\
5-64 \\
5-64 \\
35-64 \\
\\
5-64 \\
0-14 \\
0-64 \\
1-14 \\
1-64 \\
\text { all }\end{array}$ & $\begin{array}{l}010-19 \\
180 \\
180,182 \\
201 \\
393-398 \\
460-519 \\
493 \\
540-543 \\
550-553 \\
574-575 \\
400-404 \\
430-438 \\
001 \\
033 \\
037 \\
055 \\
720 \\
630-678\end{array}$ & $\begin{array}{l}010-018 \\
179 \\
179,180,182 \\
210 \\
393-398 \\
460-519 \\
493 \\
540-543 \\
550-553 \\
574-575 \\
401-405 \\
430-438 \\
001 \\
033 \\
037 \\
055 \\
720 \\
630-676\end{array}$ \\
\hline $\begin{array}{l}\text { Primary prevention, or national health policy indicators } \\
19 \text { Cirrhosis of liver } \\
20 \text { Malignant neoplasms of trachea, bronchus, and lung } \\
21 \text { Motor vehicle accidents }\end{array}$ & $\begin{array}{r}15-64 \\
5-64 \\
\text { all }\end{array}$ & $\begin{array}{l}571 \\
162 \\
\text { E810-823 }\end{array}$ & $\begin{array}{l}571 \\
162 \\
\text { E810-825 }\end{array}$ \\
\hline
\end{tabular}

* Number of maternal deaths associated with 100000 live and stillbirths.

† Number of deaths in the first week plus late foetal mortality per 1000 live and stillbirths.

\section{POPULATIONS}

The population "inhabitants/year at risk" was the total of the Valencian Community during the same period, although it always referred to 1 July of the corresponding year. For the calculation, we used data from the municipal census ( 31 December 1975) ${ }^{14}$ from the population census (28 February 1981), ${ }^{15}$ from the municipal census (1 April 1986), ${ }^{16}$ and from the population census ( 28 February 1991$)^{17}$; the intercensal growth rate was used as an instrument and was defined as the inter-annual and accumulative growth rate $^{18}$ :

$$
P_{b}=P_{a} *(1+r)^{t b-t a}
$$

where $P_{b}$ is the population in the date $t b, P_{a}$ is the population in the $t a$ date, and $r$ is the intercensal growth rate, $r$ being equal to:

$$
r=\operatorname{antilog}\left[1 /(t b-t a) *\left(\log \left(P_{b} / P_{a}\right)\right]-1\right.
$$

We used the classifications of Holland ${ }^{9}$ and Charlton. ${ }^{3}$ These classifications of avoidable death causes, and the corresponding codes (ac- cording to the International Classification of Diseases, Injuries, and Causes of Death, ICD-8 and 9) are displayed in tables 1 and 2 .

As the classifications used are not the same, we carried out an individual study of those death causes on Charlton's list which included different codes, for instance arterial hypertension (5 to 64 years), pneumonia and bronchitis ( 5 to 49 years), acute respiratory infections ( 5 to 49 years), bacterial infections ( 5 to 64 years), and deficiency anaemias ( 5 to 64 years), which are included in subsequent tables as Charlton's classification (diseases which did not coincide). Likewise, other avoidable causes of mortality only differed in relation to age (cervical cancer, asthma, Hodgkin's disease, and maternal mortality) and an individual study was not carried out (they were included in the overall research). We followed some reports ${ }^{10-12}$ in which avoidable death causes (Holland's classification) were grouped as national health policy indicators (NHPI) and medical care indicators (MCI).

DESIGN OF THE STUDY

The annual evolution between 1975 and 1990 for the whole Valencian population was studied. Avoidable mortality rates were calculated, always per 100000 inhabitants/year at risk, except for maternal mortality (per 100000 live born), perinatal mortality (per 1000 live born) and for malignant neoplasms of the cervix uterus (per 100000 women). Rates were also determined for the age group 5 to 64 years for the groups Holland classification, NHPI, MCI, and Charlton classification, as well as the general non-MCI (without including the deaths that measure the efficiency of the health system - that is, the MCI cases).

Standardisation was direct. It was undertaken in relation to three populations; firstly using the 1981 census of the Valencian Community, secondly the Spanish population in order to make national comparisons; and thirdly by using the standard population of

* CC causes which differ, in some codes, from HC codes (see table 1)

$+\mathrm{CC}$ causes with codes and ages equal to those in HC.

$¥ \mathrm{CC}$ causes with different ages from those in HC. 
Table 3 The mean number of deaths per 100000 for "avoidable deaths indcators" and the proportion of deaths by age and sex. Valencian community (1975-90)

\begin{tabular}{|c|c|c|c|c|c|c|c|}
\hline Age groups & $\begin{array}{l}\text { Total } \\
\text { mortality* }\end{array}$ & $\begin{array}{l}M C I \\
\text { rate* }\end{array}$ & $\begin{array}{l}\text { NHPI } \\
\text { rate* }^{*}\end{array}$ & $\begin{array}{l}\text { Charlton } \\
\text { classification rate* }\end{array}$ & $\begin{array}{l}M C I \\
\% \dagger\end{array}$ & $\begin{array}{l}\text { NHPI } \\
\% \dagger\end{array}$ & $\begin{array}{l}\text { Charlton } \\
\text { classification \%t }\end{array}$ \\
\hline \multicolumn{8}{|l|}{ Males } \\
\hline $0-4 \ddagger$ & $249 \cdot 6$ & $4 \cdot 1$ & $6 \cdot 1$ & - & 1.63 & $2 \cdot 44$ & - \\
\hline 5-14 & $32 \cdot 4$ & $2 \cdot 6$ & $6 \cdot 3$ & $2 \cdot 5$ & $7 \cdot 92$ & $19 \cdot 47$ & $7 \cdot 74$ \\
\hline $15-44$ & $145 \cdot 3$ & $7 \cdot 9$ & $46 \cdot 2$ & $7 \cdot 7$ & $5 \cdot 41$ & 31.79 & $5 \cdot 3$ \\
\hline $45-64$ & $940 \cdot 4$ & $102 \cdot 5$ & $187 \cdot 8$ & $20 \cdot 8$ & $10 \cdot 9$ & $19 \cdot 96$ & $2 \cdot 21$ \\
\hline $65-74$ & $3803 \cdot 7$ & - & $325 \cdot 3$ & - & - & 8.55 & - \\
\hline$\geq 75$ & $12111 \cdot 7$ & - & $68 \cdot 9$ & - & - & 0.57 & - \\
\hline \multicolumn{8}{|l|}{ Females } \\
\hline $0-4 \ddagger$ & 195.4 & $3 \cdot 7$ & $4 \cdot 2$ & - & 1.89 & $2 \cdot 14$ & - \\
\hline $5-14$ & $21 \cdot 3$ & 2 & $3 \cdot 2$ & $2 \cdot 2$ & $9 \cdot 45$ & $15 \cdot 12$ & $10 \cdot 21$ \\
\hline $15-44$ & $64 \cdot 5$ & $7 \cdot 6$ & $10 \cdot 5$ & $6 \cdot 5$ & $11 \cdot 77$ & $16 \cdot 22$ & 10.09 \\
\hline $45-64$ & $466 \cdot 5$ & $69 \cdot 1$ & $40 \cdot 1$ & $14 \cdot 4$ & $14 \cdot 81$ & $8 \cdot 6$ & 3.08 \\
\hline $65-74$ & $2059 \cdot 7$ & - & $40 \cdot 5$ & - & - & 1.96 & - \\
\hline$\geq 75$ & $9747 \cdot 8$ & - & $22 \cdot 8$ & - & - & 0.23 & - \\
\hline
\end{tabular}

* Standard mortality rates per 100000 . Reference population: Valencian Community, census 1981

† Percentages based on the total mortality rate.

$\ddagger$ Perinatal mortality not included.

$\mathrm{MCI}=$ medical care indicators; NHPI = national health policy indicators.

the European Community, ${ }^{19}$ for international comparisons. The male rate was also established.

Both linear and non-linear regression (quadratic or second order) of the changes in mortality standardised over time were used to describe the mortality trend. This type of modelling reduces the effect of random variation on mortality. The Student's two tailed $t$ test was used to determine the statistical significance of the trends. Significance levels were established at $\mathrm{p}=0.001, \mathrm{p}=0.01$, and $\mathrm{p}=0.05$.

Logarithmic transformation did not significantly improve the explanation of the variables (based on adjusted $\mathbf{R}^{2}$ ). Because of this, the linear model is the only representation. In some cases, when the adjusted $\mathrm{R}^{2}$ in the linear model was too low, the quadratic model was used. This model is an adequate test for determining the degree of non-linearity in the mortality trend, and it was also used to estimate changes in some causes of death during the period studied (ie, asthma, motor accidents, hypertension, acute respiratory infections and deficiency anaemias), which improved the adjustment. By using this procedure, even the motor accident trend turned out to be significant.

There was no adjustment study of individual mortality causes with low numbers of deaths such as typhoid, whooping cough, tetanus, measles and osteomyelitis.

We followed the method of Poikolainen and Eskola $^{20}$ in estimating the impact of medical services on avoidable causes of mortality. This was achieved by comparing the estimated value of the regression in the mortality rates with an expected rate (considering that if the impact of the medical services were to remain constant, mortality from avoidable and unavoidable causes would also remain constant). Variations in the explained rates were also calculated according to the equation model and real data, in order to establish the percentage of the relative adjustment level of the trends.

\section{Results}

Our research first took into account a total of 42403 deaths (Holland's classification) for the whole of the period studied. Altogether 13050 deaths were included in the MCI group (excluding perinatal mortality), and more than twice this number, 29353 , were included in the NHPI. In the Charlton classification a total of 4152 deaths were processed (also excluding perinatal mortality).

With regard to mean values for the period per 100000 inhabitants and sex (table 3), the results showed that the NHPIs have high rates

Table 4 Evolution of the age adjusted mortality rates per 100000 for "avoidable death indicators" (5-64 years). Period 1975-90. Index numbers and differences

\begin{tabular}{|c|c|c|c|c|c|c|c|c|c|c|c|c|c|c|}
\hline \multirow[t]{2}{*}{ Year } & \multicolumn{2}{|c|}{ Non-MCI general mortality } & \multicolumn{3}{|l|}{$H C$} & \multicolumn{3}{|l|}{ NHPI } & \multicolumn{3}{|l|}{$M C I$} & \multicolumn{3}{|l|}{$C C$} \\
\hline & Rate* & Index & Rate* & Index & $D \dagger$ & Rate $^{*}$ & Index & $D \dagger$ & Rate* & Index & $D \dagger$ & Rate* & Index & $D \dagger$ \\
\hline $\begin{array}{l}1975 \\
1976 \\
1977 \\
1978 \\
1979 \\
1980 \\
1981 \\
1982 \\
1983 \\
1984 \\
1985 \\
1986 \\
1987 \\
1988 \\
1989 \\
1990\end{array}$ & $\begin{array}{l}237 \cdot 00 \\
229 \cdot 45 \\
229 \cdot 20 \\
227 \cdot 13 \\
222 \cdot 46 \\
219 \cdot 68 \\
215 \cdot 54 \\
209 \cdot 18 \\
208 \cdot 49 \\
210 \cdot 78 \\
209 \cdot 02 \\
207 \cdot 82 \\
201 \cdot 70 \\
204 \cdot 23 \\
205 \cdot 84 \\
197 \cdot 81\end{array}$ & $\begin{array}{r}100 \\
97 \\
97 \\
96 \\
94 \\
93 \\
91 \\
88 \\
88 \\
89 \\
88 \\
88 \\
85 \\
86 \\
87 \\
83\end{array}$ & $\begin{array}{l}83 \cdot 69 \\
78 \cdot 23 \\
76 \cdot 17 \\
77 \cdot 56 \\
77 \cdot 02 \\
75 \cdot 85 \\
72 \cdot 06 \\
69 \cdot 05 \\
67 \cdot 69 \\
69 \cdot 12 \\
69 \cdot 70 \\
66 \cdot 05 \\
63 \cdot 00 \\
65 \cdot 93 \\
66 \cdot 57 \\
65 \cdot 89\end{array}$ & $\begin{array}{r}100 \\
93 \\
91 \\
93 \\
92 \\
91 \\
86 \\
83 \\
81 \\
83 \\
83 \\
79 \\
75 \\
79 \\
80 \\
79\end{array}$ & $\begin{array}{l}0 \\
-3 \\
-6 \\
-3 \\
-2 \\
-2 \\
-5 \\
-6 \\
-7 \\
-6 \\
-5 \\
-9 \\
-10 \\
-7 \\
-7 \\
-5\end{array}$ & $\begin{array}{l}40 \cdot 06 \\
41 \cdot 45 \\
42 \cdot 54 \\
44 \cdot 46 \\
44 \cdot 43 \\
44 \cdot 68 \\
43 \cdot 54 \\
41 \cdot 93 \\
42 \cdot 49 \\
44 \cdot 78 \\
45 \cdot 02 \\
44 \cdot 82 \\
44 \cdot 70 \\
46 \cdot 23 \\
49 \cdot 84 \\
49 \cdot 87\end{array}$ & $\begin{array}{l}100 \\
103 \\
106 \\
111 \\
111 \\
112 \\
109 \\
105 \\
106 \\
112 \\
112 \\
112 \\
112 \\
115 \\
124 \\
124\end{array}$ & $\begin{array}{r}0 \\
7 \\
9 \\
15 \\
17 \\
19 \\
18 \\
16 \\
18 \\
23 \\
24 \\
24 \\
26 \\
29 \\
38 \\
41\end{array}$ & $\begin{array}{l}43 \cdot 63 \\
36 \cdot 78 \\
33 \cdot 63 \\
33 \cdot 10 \\
32 \cdot 59 \\
31 \cdot 17 \\
28 \cdot 52 \\
27 \cdot 12 \\
25 \cdot 20 \\
24 \cdot 34 \\
24 \cdot 68 \\
21 \cdot 23 \\
18 \cdot 30 \\
19 \cdot 70 \\
16 \cdot 73 \\
16 \cdot 02\end{array}$ & $\begin{array}{r}100 \\
84 \\
77 \\
76 \\
75 \\
71 \\
65 \\
62 \\
58 \\
56 \\
57 \\
49 \\
42 \\
45 \\
38 \\
37\end{array}$ & $\begin{array}{l}0 \\
-13 \\
-20 \\
-20 \\
-19 \\
-21 \\
-26 \\
-26 \\
-30 \\
-33 \\
-32 \\
-39 \\
-43 \\
-41 \\
-49 \\
-47\end{array}$ & $\begin{array}{r}17 \cdot 30 \\
12 \cdot 13 \\
11 \cdot 14 \\
11.91 \\
10 \cdot 10 \\
.9 \cdot 47 \\
8 \cdot 58 \\
7 \cdot 86 \\
7 \cdot 42 \\
7 \cdot 10 \\
7 \cdot 50 \\
6.57 \\
6 \cdot 09 \\
6 \cdot 40 \\
5 \cdot 49 \\
5.68\end{array}$ & $\begin{array}{r}100 \\
70 \\
64 \\
69 \\
58 \\
55 \\
50 \\
45 \\
43 \\
41 \\
43 \\
38 \\
35 \\
37 \\
32 \\
33\end{array}$ & $\begin{array}{l}100 \\
-27 \\
-32 \\
-27 \\
-35 \\
-38 \\
-41 \\
-43 \\
-45 \\
-48 \\
-45 \\
-50 \\
-50 \\
-49 \\
-55 \\
-51\end{array}$ \\
\hline
\end{tabular}

* Standard mortality rate, the 1981 Valencian Community population has been taken as a standard

+ Differences in index numbers, compared with the non-MCI general mortality index. $\mathrm{CC}=$ Charlton's classification; Non-MCI general mortality $=$ general mortality rate minus MCI mortality rate (both for 5-64 years); HC = Holland's classification; NHPI = national health policy indicators; $\mathrm{MCI}=$ medical care indicators. 
Table 5 Annual mean rates (standardised for Spain and the European Community) per 100000 inhabitants

\begin{tabular}{|c|c|c|c|c|c|c|c|c|}
\hline \multirow[t]{2}{*}{ Cause } & \multirow[t]{2}{*}{ Age (y) } & \multicolumn{3}{|c|}{ Valencia, adjusted rates } & \multicolumn{4}{|c|}{ European population, adjusted rates } \\
\hline & & Males & Females & Total & Males & Females & Total & $M R$ \\
\hline $\begin{array}{l}\text { Medical care indicators } \\
\text { Tuberculosis } \\
\text { Malignant neoplasms of cervix uteri } \\
\text { Malignant neoplasm cervix and corpus of uterus } \\
\text { Hodgkin's disease } \\
\text { Chronic rheumatic heart disease } \\
\text { Respiratory disease } \\
\text { Asthma } \\
\text { Appendicitis } \\
\text { Abdominal hernia } \\
\text { Cholelitiasis and cholecystitis } \\
\text { Hypertensive and cerebrovascular disease } \\
\text { Maternal mortality* } \\
\text { Perinatal mortality } \\
\text { Typhoid } \\
\text { Whooping cough } \\
\text { Tetanus } \\
\text { Measles } \\
\text { Osteomyelitis }\end{array}$ & $\begin{array}{r}5-64 \\
15-64 \\
15-54 \\
5-64 \\
5-44 \\
1-14 \\
5-44 \\
5-64 \\
5-64 \\
5-64 \\
35-64 \\
\text { All } \\
5-64 \\
0-14 \\
0-64 \\
1-14 \\
1-64\end{array}$ & $\begin{array}{l}3 \cdot 19 \\
\overline{-} \\
1 \cdot 09 \\
1 \cdot 12 \\
2 \cdot 68 \\
0 \cdot 24 \\
0 \cdot 27 \\
0 \cdot 19 \\
0 \cdot 39 \\
62 \cdot 76 \\
- \\
0 \cdot 03 \\
0 \cdot 01 \\
0 \cdot 17 \\
0 \cdot 09 \\
0 \cdot 01\end{array}$ & $\begin{array}{l}0 \cdot 78 \\
1 \cdot 81 \\
2 \cdot 77 \\
0 \cdot 43 \\
1 \cdot 39 \\
2 \cdot 22 \\
0 \cdot 24 \\
0 \cdot 14 \\
0 \cdot 31 \\
0 \cdot 39 \\
38 \cdot 35 \\
11 \cdot 55 \\
0 \cdot 02 \\
0 \cdot 06 \\
0 \cdot 07 \\
0 \cdot 14 \\
0 \cdot 004\end{array}$ & $\begin{array}{c}1.93 \\
1.81 \\
2.77 \\
0.75 \\
1.26 \\
2.46 \\
0.24 \\
0.2 \\
0.26 \\
0.39 \\
49.83 \\
11.55 \\
14.04 \\
0.02 \\
0.03 \\
0.12 \\
0.11 \\
0.01\end{array}$ & $\begin{array}{l}3 \cdot 66 \\
\overline{-} \\
1 \cdot 21 \\
1 \cdot 34 \\
2 \cdot 77 \\
0 \cdot 27 \\
0 \cdot 3 \\
0 \cdot 22 \\
0 \cdot 45 \\
62 \cdot 16 \\
- \\
0 \cdot 03 \\
0 \cdot 01 \\
0 \cdot 18 \\
0 \cdot 1 \\
0.01\end{array}$ & $\begin{array}{l}0.87 \\
1.97 \\
3.09 \\
0.47 \\
1.7 \\
2.31 \\
0.29 \\
0.16 \\
0.36 \\
0.45 \\
38.02 \\
11.55 \\
0.02 \\
0.07 \\
0.08 \\
0.15 \\
0.004\end{array}$ & $\begin{array}{c}2.21 \\
1.97 \\
3.09 \\
0.83 \\
1.52 \\
2.55 \\
0.28 \\
0.23 \\
0.3 \\
0.45 \\
49.36 \\
11.55 \\
14.04 \\
0.02 \\
0.04 \\
0.13 \\
0.12 \\
0.01\end{array}$ & $\begin{array}{l}4.21 \\
- \\
2.57 \\
0.79 \\
1 \cdot 2 \\
0.93 \\
1.88 \\
0.61 \\
1.00 \\
1 \cdot 63 \\
- \\
\overline{1} \cdot 5 \\
0.14 \\
2.25 \\
0.67 \\
2.5\end{array}$ \\
\hline $\begin{array}{l}\text { National health policy indicators } \\
\text { Malign cancer of trachea, bronchus, and lung } \\
\text { Cirrhosis of liver } \\
\text { Motor vehicle accidents }\end{array}$ & $\begin{array}{r}5-64 \\
15-74 \\
\text { Todos }\end{array}$ & $\begin{array}{l}22 \cdot 62 \\
57 \cdot 37 \\
29 \cdot 49\end{array}$ & $\begin{array}{l}7 \cdot 22 \\
5 \cdot 37 \\
8 \cdot 03\end{array}$ & $\begin{array}{l}14 \cdot 57 \\
29 \cdot 01 \\
18 \cdot 29\end{array}$ & $\begin{array}{l}26 \\
58 \cdot 3 \\
29 \cdot 8\end{array}$ & $\begin{array}{l}8 \cdot 27 \\
5 \cdot 48 \\
7 \cdot 98\end{array}$ & $\begin{array}{l}16 \cdot 73 \\
29 \cdot 57 \\
18 \cdot 43\end{array}$ & $\begin{array}{r}3 \cdot 14 \\
10 \cdot 64 \\
3 \cdot 73\end{array}$ \\
\hline $\begin{array}{l}\text { Charlton's classifications (disease that differ from } \mathrm{H} \\
\text { Hypertensive disease } \\
\text { Pneumonia and bronchitis } \\
\text { Acute respiratory infections } \\
\text { Bacterial infections } \\
\text { Deficiency anaemias }\end{array}$ & $\begin{array}{l}\text { d's classification } \\
5-64 \\
5-49 \\
5-49 \\
5-64 \\
5-64\end{array}$ & $\begin{array}{l}1 \cdot 67 \\
2 \cdot 58 \\
0 \cdot 31 \\
0 \cdot 64 \\
0 \cdot 08\end{array}$ & $\begin{array}{l}0.97 \\
1 \cdot 32 \\
0 \cdot 19 \\
0 \cdot 43 \\
0 \cdot 06\end{array}$ & $\begin{array}{l}1 \cdot 3 \\
1 \cdot 94 \\
0.25 \\
0.53 \\
0.07\end{array}$ & $\begin{array}{l}1 \cdot 91 \\
2 \cdot 79 \\
0.34 \\
0.68 \\
0.09\end{array}$ & $\begin{array}{l}1 \cdot 1 \\
1 \cdot 4 \\
0 \cdot 2 \\
0 \cdot 44 \\
0 \cdot 06\end{array}$ & $\begin{array}{l}1 \cdot 48 \\
2.09 \\
0.27 \\
0.56 \\
0.08\end{array}$ & $\begin{array}{l}1.74 \\
1.99 \\
1.7 \\
1.55 \\
1.5\end{array}$ \\
\hline $\begin{array}{l}\text { Disease groups (total) } \\
\text { Medical care indicators } \ddagger \emptyset \\
\text { National health policy indicators } ₫ \\
\text { Charlton's classification } \ddagger \S\end{array}$ & $\begin{array}{l}\text { All avoidable } \\
\text { All avoidable } \\
\text { All avoidable }\end{array}$ & $\begin{array}{r}26 \cdot 73 \\
87 \cdot 95 \\
8 \cdot 19\end{array}$ & $\begin{array}{r}18 \cdot 44 \\
17 \cdot 62 \\
6 \cdot 12\end{array}$ & $\begin{array}{r}22 \cdot 32 \\
50 \cdot 38 \\
7 \cdot 12\end{array}$ & $\begin{array}{r}30 \cdot 69 \\
94 \cdot 05 \\
9 \cdot 13\end{array}$ & $\begin{array}{r}21 \cdot 15 \\
18 \cdot 74 \\
6 \cdot 83\end{array}$ & $\begin{array}{r}25 \cdot 61 \\
53 \cdot 87 \\
7 \cdot 94\end{array}$ & $\begin{array}{l}1.45 \\
5 \cdot 02 \\
1 \cdot 34\end{array}$ \\
\hline
\end{tabular}

* Rate per 100000 born alive; trate per 1000 born alive (data from 1975-90).

$\ddagger$ Perinatal mortality is not included; $\$$ from 5 to 64 .

$\mathrm{MR}=$ Male rate.

for ages 65 to 74 and more than 75 years for both sexes, although rates are even higher for men. Charlton classification rates are a lot lower, the highest rate was in the 45-64 years age group for both men and women. In the Holland classification, however, avoidable causes of death for men were most important in the 15-44 years age group which accounted for approximately $38 \%$ of the total mortality (especially due to NHPI (32\%)) followed by the 45-64 age group which accounted for $31 \%$ (the NHPI represented 20\%). The results for women were similar. The 15-44 age group was most important, representing approximately $28 \%$ of the total mortality for the age group; however, the MCI proportion was larger (12\%) than in males. The next highest group was the 5-14 age group, with a $10 \% \mathrm{MCI}$, and the 45-64 age group in which we observed the highest MCI, approximately $15 \%$, which was higher than the NHPI.

With regard to the evolution of mortality during the period (table 4) and referring to the indices, a reduction in unavoidable mortality of approximately $17 \%$ was observed, whereas for avoidable mortality the Holland classification was reduced by $21 \%$, especially due to the MCIs, which were reduced to $63 \%$, while NHPI increased to $24 \%$. A transverse comparison shows the differences on an annual basis. The NHPI presented a clearly growing trend with some years of intense growth, whereas the opposite happened in the case of MCI.

The mean rates per 100000 inhabitants for the period were then studied according to cause of death and adjusted to the standard of the
Spanish population and that of Europe (table 5). The NHPI was the most important with a mean rate of 50.38 , whereas men reached values of up to $87 \cdot 95$. We can make practically the same comments when applying the adjusted rates to the European Community, although the values increased proportionally. The Charlton classification chart, however, retained low values $-7 \cdot 12$ for the total. The male rate was also noteworthy - it was 11 in the case of cirrhosis, 4 in tuberculosis, and 3 in motor accidents and lung cancer. However, in women (excluding specific causes for this group) we found values of 0.15 for deficiency anaemias and whooping cough, 0.6 for hernias, and 0.8 for chronic rheumatic heart disease.

Adjustment of the trends of the standardised rates to the Valencian Community population (1981) for the period 1975-90 (table 6) was carried out, and a positive trend for the adjusted NHPI slope was found, showing a growth of 0.5 points per year. The rest of the slopes were negative. The $\beta$ coefficients of MCI $(\mathrm{t}=$ $-17 \cdot 8)$, Holland classification $(t=-9 \cdot 27)$ and Charlton classification ( $t=-7 \cdot 98)$ were negative and significant $(p<0.001)$. With regard to the different avoidable causes, all were negative, except for cervical cancer, hepatic cirrhosis, and motor accidents.

The figure shows the evolution of the standardised mortality rates (general and avoidable mortality - Holland's classification - and mortality for the MCI and NHPI) from age 5 to 64 years for the period 1975-90 in the Valencian Community (in a logarithmic scale). General mortality shows a slightly falling trend and the evolution of the avoidable mortality rates are 
Table 6 Parameters of adjustment to the avoidable cause trend (1975-90), on calendar year and rate variation

\begin{tabular}{|c|c|c|c|c|c|c|}
\hline \multirow[t]{2}{*}{ Cause } & \multirow[t]{2}{*}{ Age (y) } & \multicolumn{2}{|c|}{ Per 100000 inhabitants } & \multirow{2}{*}{$\begin{array}{l}\text { Regression } \\
\text { coefficient }\end{array}$} & \multicolumn{2}{|c|}{ Rate variation $1975-90(\%)$} \\
\hline & & $\begin{array}{l}\alpha \\
\text { coefficient }\end{array}$ & $\begin{array}{l}\beta \\
\text { coefficient }\end{array}$ & & $\begin{array}{l}\text { by } \\
\text { regression }\end{array}$ & $\begin{array}{l}\text { by } \\
\text { standard* }\end{array}$ \\
\hline $\begin{array}{l}\text { Medical care indicators } \\
\text { Tuberculosis } \\
\text { Malignant neoplasms of cervix uteri† } \\
\text { Malignant neoplasms of cervix and body of uterus } \dagger \\
\text { Hodgkin's disease } \\
\text { Chronic rheumatic heart disease } \\
\text { Respiratory diseases } \\
\text { Asthma (QR) } \\
\text { Appendicitis } \\
\text { Abdominal hernia } \\
\text { Cholelithiasis and cholecystitis } \\
\text { Hypertensive and cerebrovascular disease } \\
\text { Maternal mortality } \ddagger \\
\text { Perinatal mortality } \$\end{array}$ & $\begin{array}{r}5-64 \\
15-64 \\
15-54 \\
5-64 \\
5-44 \\
1-14 \\
5-44 \\
5-64 \\
5-64 \\
5-64 \\
35-64 \\
\text { All }\end{array}$ & $\begin{array}{l}3 \cdot 148 \\
0.941 \\
4 \cdot 764 \\
1 \cdot 14 \\
2 \cdot 533 \\
4 \cdot 489 \\
9739 \\
0.374 \\
0.428 \\
0.572 \\
67 \cdot 564 \\
21 \cdot 344 \\
17 \cdot 316\end{array}$ & 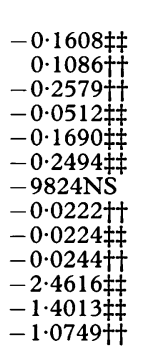 & $\begin{array}{l}0 \cdot 83 \\
0.546 \\
0.514 \\
0.729 \\
0.791 \\
0.687 \\
0.266 \\
0.535 \\
0.684 \\
0.419 \\
0.931 \\
0.733 \\
0.508\end{array}$ & $\begin{array}{c}-76 \cdot 5 \\
73 \\
-81 \cdot 11 \\
-67 \cdot 57 \\
-100 \cdot 09 \\
-83 \cdot 29 \\
-23 \cdot 91 \\
-89 \cdot 33 \\
-79 \cdot 02 \\
-63 \cdot 32 \\
-54 \cdot 65 \\
-98 \cdot 5 \\
-62 \cdot 07\end{array}$ & $\begin{array}{r}-71 \cdot 21 \\
89 \cdot 56 \\
-57 \cdot 54 \\
-66 \cdot 13 \\
-84 \cdot 95 \\
-58 \cdot 05 \\
-34 \cdot 92 \\
-88 \cdot 78 \\
-74 \cdot 19 \\
-66 \cdot 67 \\
-59.8 \\
-76 \cdot 65 \\
-56 \cdot 46\end{array}$ \\
\hline $\begin{array}{l}\text { National health policy indicators } \\
\text { Malignant neoplasms of trachea, bronchus and lung } \\
\text { Cirrhosis of the liver } \\
\text { Motor vehicle accidents (QR) }\end{array}$ & $\begin{array}{l}5-64 \\
15-64 \\
\text { All }\end{array}$ & $\begin{array}{r}15 \cdot 693 \\
21.837 \\
209946\end{array}$ & $\begin{array}{r}-0 \cdot 1837 \text { 执 } \\
0 \cdot 8451 \neq \neq \\
211 \cdot 82^{* *}\end{array}$ & $\begin{array}{l}0.652 \\
0.878 \\
0.423\end{array}$ & $\begin{array}{r}-17 \cdot 54 \\
58 \cdot 03 \\
16 \cdot 83\end{array}$ & $\begin{array}{r}-11 \cdot 8 \\
52 \cdot 91 \\
18 \cdot 24\end{array}$ \\
\hline $\begin{array}{l}\text { Charlton's classification (disease that differ from Hollan } \\
\text { Hypertensive disease (QR) } \\
\text { Pneumonia and bronchitis } \\
\text { Acute respiratory infections (QR) } \\
\text { Bacterial infections } \\
\text { Deficiency anaemia (QR) }\end{array}$ & $\begin{array}{l}\text { sification) } \\
5-64 \\
5-49 \\
5-49 \\
5-64 \\
5-64\end{array}$ & $\begin{array}{r}15596 \\
3.031 \\
26242 \\
0.745 \\
4426\end{array}$ & $\begin{array}{l}-15 \cdot 7 \mathrm{NS} \\
-0 \cdot 1453 \neq \ddagger \\
-26 \cdot 46^{* *} \\
-0 \cdot 0291 \neq \ddagger \\
-4 \cdot 457 \mathrm{NS}\end{array}$ & $\begin{array}{l}0 \cdot 41 \\
0 \cdot 738 \\
0 \cdot 45 \\
0 \cdot 587 \\
0 \cdot 33\end{array}$ & $\begin{array}{l}-34 \cdot 28 \\
-71 \cdot 96 \\
-91 \cdot 13 \\
-58 \cdot 43 \\
-90 \cdot 16\end{array}$ & $\begin{array}{l}-40 \cdot 93 \\
-77 \cdot 95 \\
-94 \cdot 81 \\
-53 \cdot 05 \\
-100\end{array}$ \\
\hline $\begin{array}{l}\text { Disease groups (total) } \\
\text { Medical care indicators } \\
\text { National health policy indicators } \\
\text { Holland's classification } \\
\text { Charlton's classification } \\
\text { Total mortality }\end{array}$ & $\begin{array}{l}5-64 \\
5-64 \\
5-64 \\
5-64 \\
5-64\end{array}$ & $\begin{array}{l}39 \cdot 043 \\
41 \cdot 031 \\
80 \cdot 08 \\
13 \cdot 25 \\
270 \cdot 989\end{array}$ & $\begin{array}{l}-1 \cdot 5997 \ddagger \ddagger \\
0 \cdot 4527 \ddagger \ddagger \\
-1 \cdot 147 \ddagger \ddagger \\
-0 \cdot 5950 \ddagger \ddagger \\
-3 \cdot 8810 \ddagger \ddagger\end{array}$ & $\begin{array}{l}0 \cdot 957 \\
0 \cdot 661 \\
0 \cdot 86 \\
0 \cdot 819 \\
0 \cdot 952\end{array}$ & $\begin{array}{r}-61 \cdot 45 \\
16 \cdot 54 \\
-22 \cdot 98 \\
-67 \cdot 34 \\
-21 \cdot 45\end{array}$ & $\begin{array}{l}-63 \cdot 29 \\
24 \cdot 49 \\
-21 \cdot 3 \\
-67 \cdot 17 \\
-23 \cdot 67\end{array}$ \\
\hline
\end{tabular}

* Standardised rates according to the Valencian Community population (census 1981); † Rates per 100000 women; $\ddagger$ Rates per 100000 live born; $\S$ Rates per 1000 live born (data from 1975-86). NS=Non-significant; ${ }^{* *} \mathrm{p}<0.05 ;+\dagger \mathrm{p}<0 \cdot 01 ; \neq \neq \mathrm{p}<0.001$. $\mathrm{QR}=\mathrm{Quadratic}$ regression

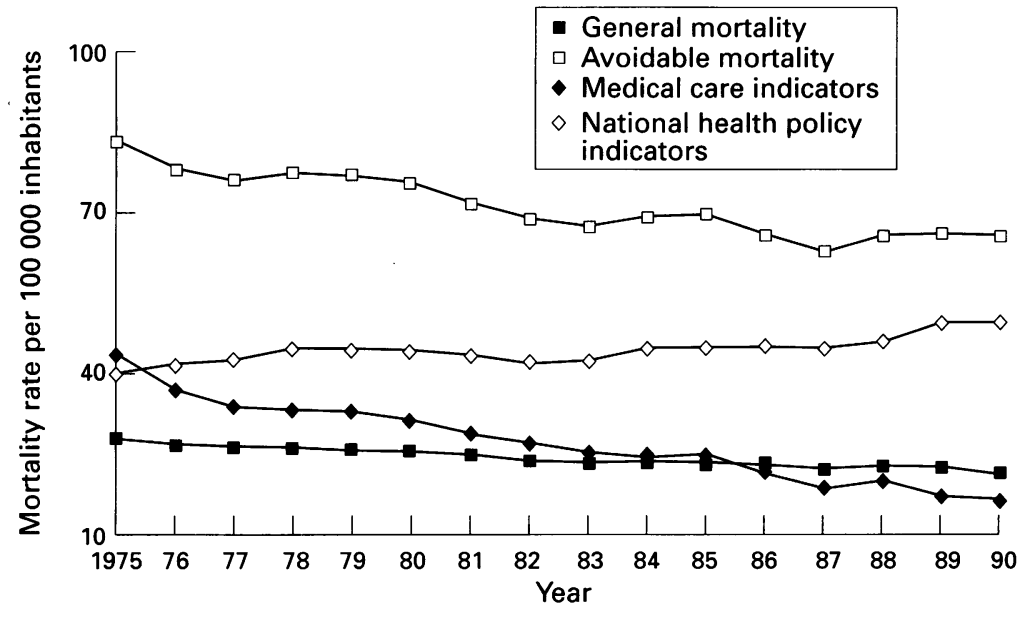

Evolution of age adjusted mortality rates, avoidable mortality (Holland classification), and National health policy indicators and medical care indicators in the Valencian Community 1975-90. importance - the MCI group and the NHPI, representing $11 \%$ and $19 \%$ respectively of the total mortality. Some similarities between the Charlton classification and the MCI must be taken into consideration as well as the fact that their relative difference is a result of cerebrovascular diseases, which accounted for $70 \%$ of the total MCI. In fact, the rates for the 5-14 and 15-44 year groups, both for men and women, are practically equal as cerebrovascular diseases are more common in old age.

Secondly, it is important to mention the contribution of men to avoidable mortality, especially in the NHPI group, which showed a male rate of 5 . The male rate was also important in the MCI group (1.45), despite the existence of diseases which only affect women, such as cervical cancer and maternal mortality. The same applies to the Charlton classification, although the male rate $(1 \cdot 3)$ was slightly lower than the value for Spain, published in another paper covering the period $1975-84 .{ }^{21}$

The rapid decline in mortality for both the MCI group and in Charlton's classification seems interesting, as both showed a homogeneous answer in the research. On the othe hand, the reduction in causes derived from health policies, promotion, and prevention present us with an important increase in other areas. As to specific causes, we find important reductions in deaths due to deficiency anaemias, acute respiratory infections, appendicitis, and chronic rheumatic heart disease. This may point to the selective efforts of the health system, while there are causes that show considerable increases, such as cervical cancer, hepatic cirrhosis, and motor accidents. In other countries such as Sweden, however, there have

\begin{abstract}
$4 \%$. The practical usefulness of the Holland classification stems from its ability to differentiate between two groups that have difffering

Discussion

Firstly, and with regard to the 5 to 64 of the classifications on the contribution of avoidable mortality to global mortality. For the period 1955-90, the Holland classification represented $30 \%$ of general mortality whereas the Charlton classification represented only
\end{abstract}


been decreases in all avoidable causes except for lung cancer for the period 1974-85. ${ }^{11}$

The comparison between reductions in mortality due to avoidable and unavoidable causes suggests the impact level of the health services on mortality. Comparisons for the 1975-90 period for the Valencia Community indicate that approximately $46 \%$ of the decrease (taking into account the difference in the MCI indexes of avoidable mortality in the 5-64 age group) is due to the intervention of the health system, which implies a $2.9 \%$ annual decrease during the period. This assumption is based on the reasoning that in the absence of health services, the decrease in avoidable mortality would have been equal to that for unavoidable causes. Other authors showed for Finland ${ }^{20}$ a reduction effect of the health system of $50 \%$ for the period $1969-81$, which is equivalent to a $3 \cdot 85 \%$ annual reduction, although we consider that this report was based on a somewhat different classification of avoidable causes and on a previous period of time.

Some aspects, such as the possible effects of the accuracy of the death certificates and the differences in coding, especially as a result of the code changes in ICD- 8 and ICD-9, have to be taken into account. In a study in which $25 \%$ of the deaths in England and Wales ${ }^{10}$ were coded according to two classifications, the differences were lower than $10 \%$ for each of the avoidable causes, except for chronic rheumatic heart disease, which showed considerable differences. The present study did not show differences as a result of coding changes.

Variability in evolution over time could also arise as a result of uneven distribution in incidence, prevalence, and/or lethality; although control of the potentially avoidable factors which could lead to death should be the same. ${ }^{22}$ As proof of this potential control of the situation, confidential enquiries carried out for diverse death causes showed that the deficiencies in the services have been overcome. ${ }^{23-25}$

The joint assessment of the indicator group could also function as an indicator for the distribution of resources in the health sector, whereas the individual use of MCI could be as a quality control of the results of the health care process, and even as an indicator in relation to the management of the services through the assessment of their effectiveness; the NHPI assessment would provide valuable information about the efficiency of the primary prevention measures at a collective level and public health measures applied previously. The slight fall in general mortality over the period studied obviously coincides with a situation in which it is difficult to obtain considerable reductions in the rates. We must also take into account the fact that increased life expectancy (with the subsequent increase of the older population) increases avoidable mortality rates in most developed countries. The same happens with the avoidable mortality rate, the reduction in its two components being most important. Indeed, the steeply falling trend in the MCI group points at achievements in health care; however, the increase in NHPI mortality shows the difficulties in improvement in this regard without carrying out major reforms in the public health arena. Some examples of these - mortality linked to tobacco, ${ }^{26}$ motor accidents, ${ }^{27}$ and mortality related to dieting habits ${ }^{28}$ - evidently require efficient measures, not only on a health basis, and results are not evident for some time as most of these diseases have a long latency period.

Supported by a grant of Consellería de Sanitat i Consum de la Generalitat Valenciana, no ref 26/91.

1 Rutstein DD, Berenberg W, Thomas C, et al. Measuring the quality of medical care. $N$ Engl f Med 1976;294:582-8.

2 Rutstein DD, Berenberg W, Thomas C, et al. Measuring the quality of medical care: second revision of tables of indexes. N Engl f Med 1980;302:1146-50.

3 Charlton JRH, Hartley RM, Silver R, Holland WW. Geographical variation in mortality from conditions amenable to medical intervention in England and Wales. Lancet to medical in

4 McKee M, Bewley B. Preventable mortality in Northern Ireland. Ir Med f 1987;80:229-31.

5 Gispert R, Rue M, Ortun V. Exploración de la mortalidad prematura como guía de política sanitaria e indicador de calidad asistencial. Med Clin 1988;90:399-403.

6 Bernat LM, Rathwell T. The effect of health services on mortality: amenable and non-amenable causes in Spain. Int $\mathcal{F}$ Epidemiol 1989;18:652-7.

7 González J, Cerda T, Regidor E, Medrano MJ. Atlas de mortalidad evitable en España. Madrid: Ministerio de Sanidad y Consumo, 1989.

8 De Marco R, Zanolin ME. Mortalita per alcune cause riconducibili allíntervento medico nelle USL Lombarde (1980-1985). Epidemiol Prev 1990;12:24-32.

9 Mackenbach JP, Kunst AD, Looman CWN, Habbema JDF, Van der Maas PJ. Regional differences in decline of mortality from selected conditions: The Netherlands, 19691984. Int F Epidemiol 1988;17:86-9.

10 Holland WW. Commission of the European Communities. European Community atlas of "avoidable death". Health Services Research, Series no 3. Oxford: Oxford Medical Publications, 1988.

11 Holland WW. Commission of the European Communities. Eumpean Community atlas of "avoidable death". Health Services Research, Series no 6, Vol 1. Oxford: Oxford Medical Publications, 1991.

12 Westerling $R$, Smedby B. The European Community "avoidable death indicators" in Sweden 1974-1985. Int f avoidable death indicators

13 Alfonso JL, Sanchis B, Prado MJ, Sabater A, Cortina P. Testing a new health indicator: using avoidable causes of death and life expectancy for Spain between 1975-1985. Eur f Epidemiol 1993;9:33-9.

14 INE. Padrón municipal de habitantes 1975. 1st Ed. Vol 7. Madrid: Ministerio de Economia, 1978.

15 INE. Censo de población 1981. Tomo 3, Madrid: Ministerio de Economía, 1984.

16 Consellería de Economía y Hacienda. Padrón municipal de habitantes 1986. Valencia: Generalitat Valenciana, 1987.

17 Institut Valenciá d'Estadística. Anuario estadistico de la Comunidad Valenciana 1991. Valencia: Generalitat Valenciana, 1992.

18 Consellería de Economia y Hacienda. Evolución de la población desde 1900 hasta 1986. Valencia: Generalitat Valenciana, 1987.

19 Rumeau-Rouquette C, Greart G, Padieur R. Méthodes en épidemiologie. Paris: Flammarion Medicine Sciences, 1985

20 Poikolainen K, Eskola J. The effect of health services on mortality: decline in death rates from amenable and nonamenable causes in Finland 1969-81. Lancet 1986; i:199202.

21 Gispert R. La mortalidad evitable. ¿Indicator de calidad asistencial? Control de Calidad Asistencial 1992;7:1-7.

22 Singal GM, Stillwell PJ, Chambers J, Clews B. A confidential enquiry into premature preventable deaths. Pilot study. Walsall: Walsall Health Authority. England, 1985.

23 Cloake E. Report on confidential enquiries into maternal deaths in the United Kingdom 1985-1987. A summary
deaternal deaths in the United Kingdom 1985-1987. A
of the main points. Health Trends 1991;23:4-5.

24 Taylor EM, Emery JL. Categories of preventable unexpected Taylor EM, Emery JL. Categories of preventable
infant deaths. Arch Dis Child 1990;65:535-9.

25 Palacios S, Ondiviela R, Toledo A. Muertes potencialmente evitables. Análisis de los factores de error. Control de Calidad Asistencial 1988;3:15-17.

26 Cortina P. Sabater A, Saiz C, González JI, Alfonso JL Tendencias de la mortalidad por cáncer en España, en especial del cáncer de pulmón, en comparación con otro paises desarrollados. Gac Sanit 1994;8:162-8.

27 Prada R, Alvarez FI. Accidentes de tráfico: ¿Un problem médico? Mapfre Medicina 1994;5:219-27.

28 Corella D. Indicadores de salud seleccionados: correlación entre factores alimentarios y tabaco, y mortalidad por enfermedades crónicas, España (1965-1989). Valencia: Universidad de Valencia, 1994. (PhD thesis.) 